\title{
A MECHANISM OF BASAL ICE-LAYER FORMATION INVOLVING MAJOR ICE-FABRIC CHANGES
}

\author{
By J.-L. TISON and R.D. LORRAIN
}

(Laboratoire de Géomorphologie, Faculté des Sciences, Université Libre de Bruxelles,

B-1050 Bruxelles, Belgium)

ABSTRACT. An opportunity to analyse the mechanism for the formation of a basal ice layer was provided by Glacier de Tsanfleuron in the Swiss Alps. This glacier has some lateral subglacial cavities in which a basal ice layer forms on the bedrock floor and is subsequently incorporated at the base of the glacier. Petrographic and crystallographic analyses of the different types of ice have provided a means of investigating the successive stages of the process. These analyses show major structural changes which provide field confirmation of the deformation mechanisms studied by several authors in laboratory experiments.

\section{INTRODUCTION}

Alpine glaciers often have at their bases an ice layer, up to about $1 \mathrm{~m}$ thick, which is clearly different from the glacier ice above. This basal ice layer contains much more debris than the glacier ice which is almost particle-free. It is generally stratified and consists of a sequence of different types of layers with variable thicknesses. In most cases, bubble-poor ice layers (almost particle-free and $0.2-3 \mathrm{~cm}$ thick) alternate with ice-cemented debris layers of about the same thickness. Several authors have paid attention to the origin of these basal ice layers, either on a theoretical basis related to glacier-sliding processes (Lliboutry, 1964-65, p. 689; Weertman, 1964; Robin, 1976) or through field observations, ice-fabric, chemical or isotopic analyses (Kamb and LaChapelle, 1964; Boulton, 1970; Vivian, 1975; Hallet and others, 1978; Souchez and
Lorrain, 1978; Jouzel and Souchez, 1982; Souchez and De Groote, 1985). On the one hand, these studies emphasize the role of refreezing of melt water at the base of Alpine glaciers and on the other the resulting incorporation of debris within the basal ice layer and its transfer down-glacier by displacement of the ice. In spite of the numerous studies cited above, there is a lack of observations concerning the way a basal ice layer is formed. This paper describes the mechanism for the formation of an unusual kind of basal ice layer observed in the Alps. Fabric analyses of different ice layers allow us to follow the successive stages of the process. These analyses show major structural changes that are the field illustration of the fabric changes obtained by the artificial deformation of ice samples.

\section{STUDY SITE}

The field work was carried out on Glacier de Tsanfleuron, which is located north-west of the town of Sion in the Swiss Alps. This little plateau glacier, extending over about $4 \mathrm{~km}^{2}$ between 2420 and $2850 \mathrm{~m}$ a.s.1., flows towards the east on Cretaceous limestones. A conspicuous morainic ridge dating from 1860 (Maire, unpublished) trends parallel to the glacier margin (Fig. 1). Up-stream of this ridge, the glacier retreat has exposed a smooth striated bedrock surface carved into the massive limestone, which is locally covered by a veneer of glacial debris.

Occasionally, fluted moraines, some of them up to

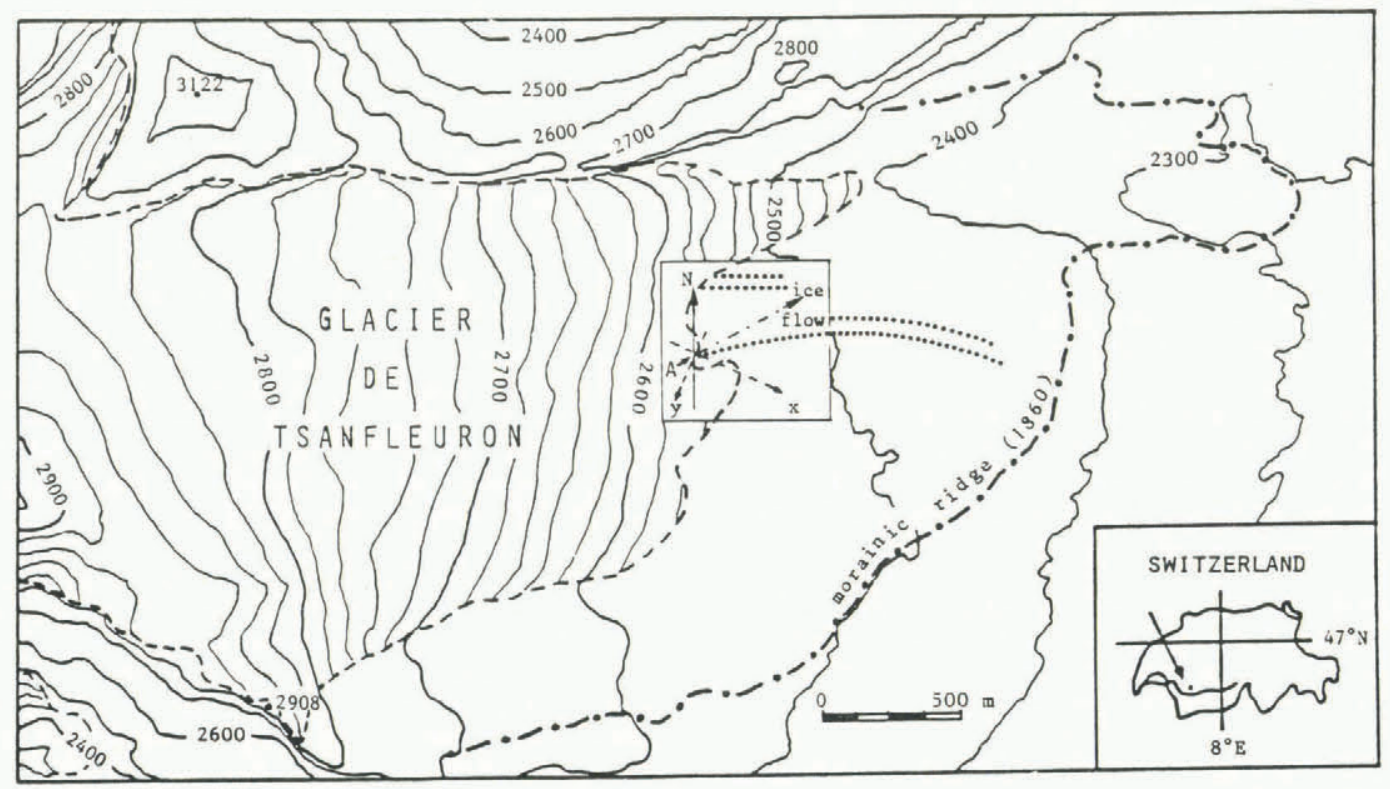

Fig. 1. Location map. The ice margin is shown by the pecked line and the moraines are dotted. The framed area around the sampling site (A) gives the reference directions for the fabric-analysis diagrams. 


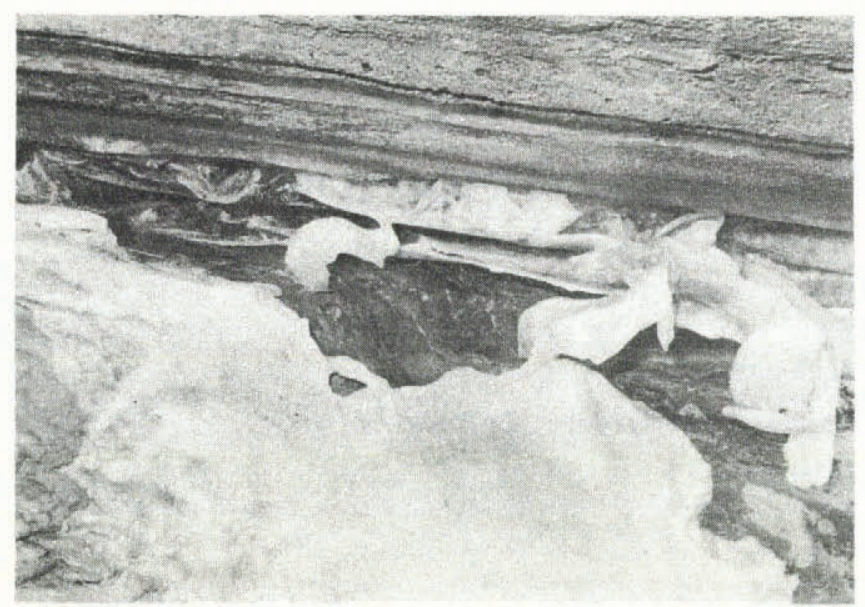

Fig. 2. One of the cavities studied at the margin of Glacier de Tsanfleuron. Note the continuous ice coating on the bedrock floor (lower left), the folded sheets of ice removed from the bedrock (middle), and the basal part of the glacier (top). The glacier ice flows from left to right; the part of the cavity shown in the photograph is $3.5 \mathrm{~m}$ long.

several hundred metres long, extend eastward from the glacier margin. This is the case in the immediate vicinity of the study site indicated on Figure 1. This site consists of two tunnel-like cavities, about $10 \mathrm{~m}$ long and 2 or $3 \mathrm{~m}$ wide, which are formed as the glacier slides over a series of roches moutonnées. As these features are located at the edge of the glacier, the ice is thin so that it loses contact with the bed between the roches moutonnees, forming décollements 2 or $3 \mathrm{~m}$ high. They offer an excellent opportunity to observe what happens at the ice-bedrock interface.

\section{MECHANISM OF FORMATION OF THE OBSERVED BASAL ICE LAYER} cavities:

The following features are present in these natural

(a) The polished bedrock floor is coated with ice layers $1-10 \mathrm{~cm}$ thick, extending over most of the surface even where the slope is steep as, for instance, on the side of a roche moutonnée (Fig. 2). These coatings are generally bubble-free and always have, at their contact with the bedrock, a thin debris layer 1-2 mm thick. In some cases, such debris layers also occur within these coatings, parallel to the ice-bedrock interface. Up to five of these debris layers have been observed in an $8 \mathrm{~cm}$ thick ice coating.

(b) In some places, especially along the up-glacier margins of the cavities, these ice coatings are fractured, detached from the bedrock, deformed, and even folded, giving rise to twisted sheets of ice (Figs 2, 3, and 4).

(c) At the down-glacier margins of the cavities, where the glacier again makes contact with the bedrock, these contorted ice layers are picked up, stretched, and dragged along by the glacier movement and thus progressively form a basal ice layer (Figs 2, 3, and 4).

The alternation of ice and debris layers, which characterizes this basal ice layer, may be achieved either during the formation of the ice coatings or by subsequent recumbent folding as is explained below:

(a) In the first case, water enters the cavity from the up-glacier direction and the penetration of cold air allows refreezing. As observed, this can occur overnight. Occasionally, a substantial amount of debris is spread over the ice coatings, either carried by the water or by falling from the ceiling. Later on, when frozen in, these particles

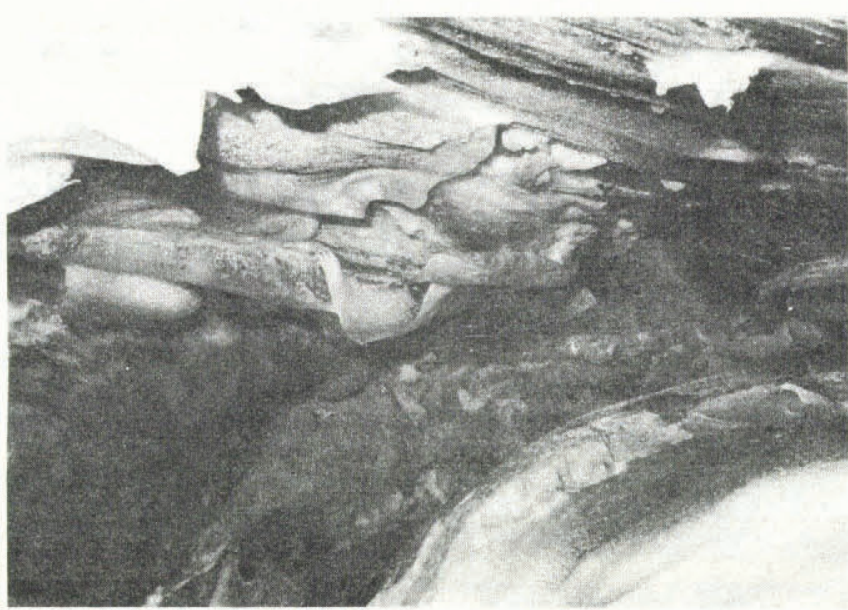

Fig. 3. Detail of the down-glacier part of the second cavity. The glacier flows from upper left to middle right. Note the twisted sheets of ice on the roof of the cavity and the folded ice coating incorporated in the basal ice layer (in the background). The ice accretion hanging from the ceiling in the upper right corner is $15 \mathrm{~cm}$ wide.

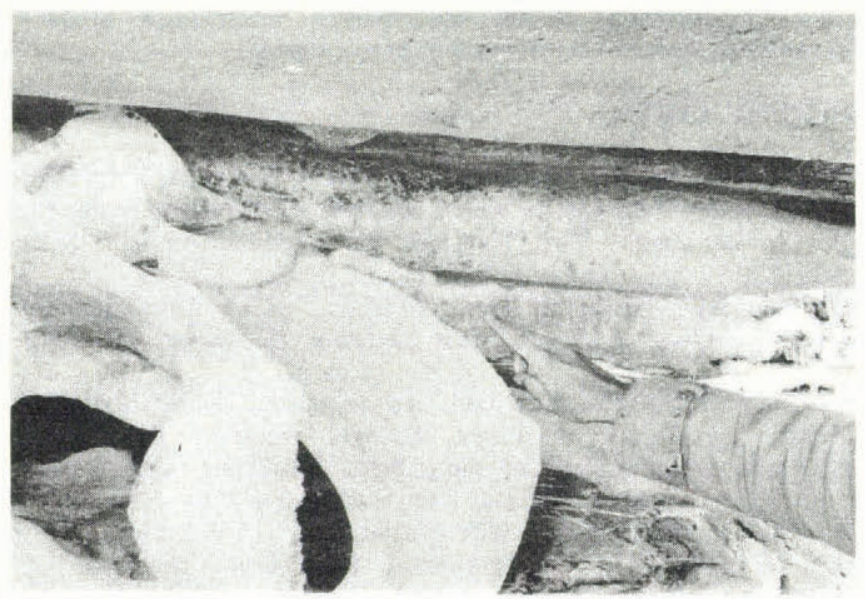

Fig. 4. Close-up view of the folded ice coating and of the basal part of the glacier. The finger points to the basal ice layer and glacier ice occurs in the upper part of the photograph.

form a debris layer in the ice coating. A sequence of such events builds up the observed layering.

(b) In the second case, a downward movement of the up-glacier margin of the cavity drags the ice coatings along, detaches them from the bedrock, and causes folding. Such changes in the form of the cavity, observed from one year or even one summer month to another, also modify its down-glacier margin. Here, the folds are subsequently pinched between the glacier sole and the bedrock, and become recumbent. This allows repetition of the debris-layer sequence within the basal ice layer.

Samples of the incoming water have been analysed for their isotopic composition in $8 D$ and $6^{18} \mathrm{O}$. This was done for the ice coatings, for different layers of the basal ice layer, and also for glacier ice sampled above the cavities. The results of these analyses, which have been published elsewhere (Lemmens and others, 1982), show that the layers in the basal ice layer have an isotopic composition completely different from that of the glacier ice but very similar to that of the ice coating the floor of the cavities. They also indicate that these coatings are produced by freezing of water flowing into the cavities. These results therefore add some weight to the suggestions made above. 


\section{ICE FABRICS}

The different types of ice observed have been sampled for petrographic and crystallographic analyses. The thin sections were made in the field using the techniques described by Langway (1958), and the fabric diagrams were drawn following standard methods (Langway, 1958; Hooke, 1969). In Figure 5, ice-crystal boundaries and $c$-axes are compared for the different types of ice. The optic axes are plotted on the lower hemisphere of a Schmidt projection, with the flow direction indicated on each diagram. In all cases, the thin sections were cut parallel to the bed and " $n$ " is the number of axes measured.

\section{Glacier ice (Fig. 5, T4)}

The thin section shows large crystals $(3-4 \mathrm{~cm})$ with imbricated margins and a large number of spherical bubbles. Most of the $c$-axes are clustered in one maximum, $45^{\circ}$ to the vertical. It should be noted, however, that the distribution of some of the optic axes suggests the presence of a small girdle around the vertical.

In Figure 6 is plotted the theoretical pattern of $c$-axes for the case of a pure shear (longitudinal compression and vertical extension), which is a possible stress field in the ablation area near the margin of the glacier. This pattern implies two maxima at $45^{\circ}$ to the vertical and in the plane of the principal stresses. Now, if the stress is sufficiently strong, the shear plane $\tau_{2}$ might become an effective sliding plane, leading to instability of the maximum $M_{1}$ and to reinforcement of maximum $\mathrm{M}_{2}$ as deformation proceeds, since the basal planes of the crystals become parallel to the sliding plane. The occurrence of a stress $\sigma_{2}$ during the deformation history of the ice T4 might explain the small girdle suggested on this diagram, thus describing a general three-dimensional stress pattern (Kamb, 1972). The flow direction deduced from the conclusions developed above is

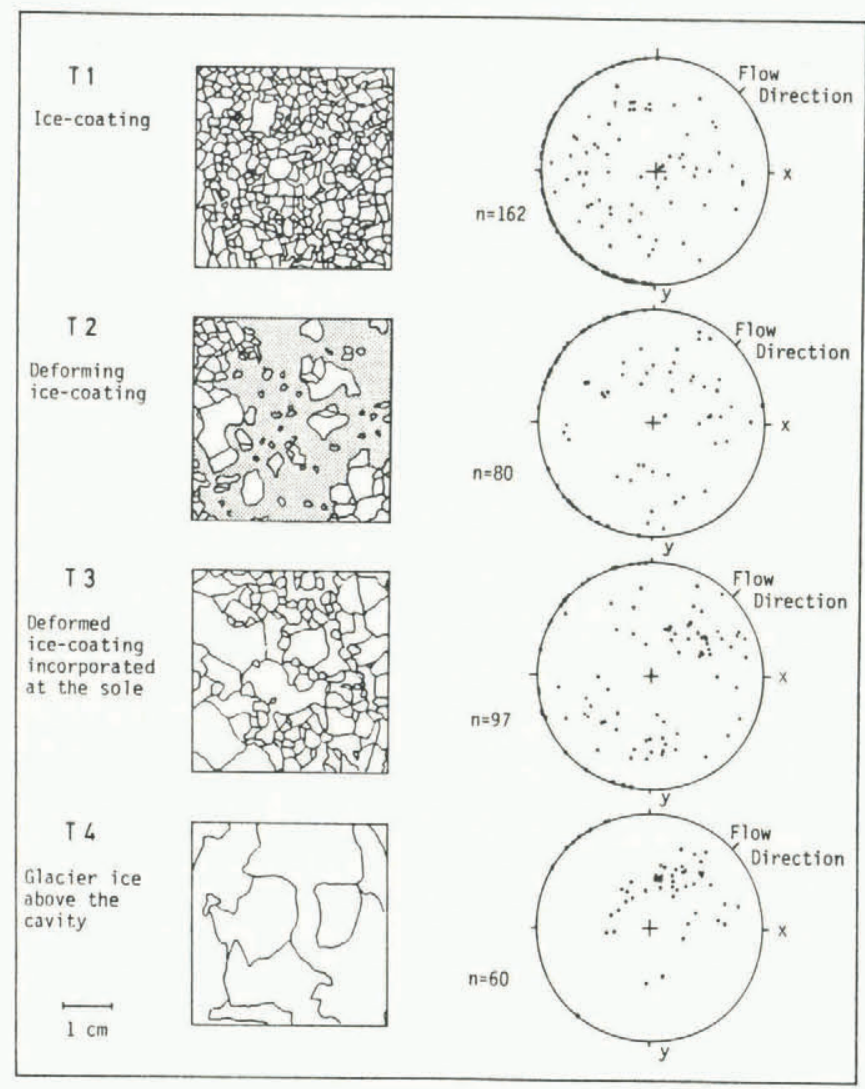

Fig. 5. Line drawings of crystal boundaries and fabric diagrams of the different types of ice sampled in the subglacial cavities of Glacier de Tsanfleuron. The thin sections were cut parallel to the bedrock. " $n$ " is the number of crystals measured. Because of software requirements, all the equatorial optic axes are plotted on the left-hand side of the diagrams. The dotted area in $T 2$ represents the microcrystalline ice matrix. in general agreement with the alignment of the most recent part of the fluted moraines near the study site and with the present-day movement of the glacier.

\section{Ice coatings on the cavity floor (Fig. 5, T1)}

In a plane perpendicular to their elongation (i.e. parallel to the bedrock), the shape of the crystals is anhedral and their cross-section varies from $2 \mathrm{~mm}^{2}$ at the base of the layer to $10 \mathrm{~mm}^{2}$ near the surface. The optic axes either lie in the horizontal plane $(45 \%$ equatorial) or are scattered in a random pattern.

The run-off frequently observed on the ice surface in summer, the elongation of the crystals in a direction perpendicular to the bedrock, the perfect fit of the ice coatings to the bedrock irregularities, and the total lack of contact with the glacier ice above strongly suggest a congelation process. The fabric of congelation ice has been reported in detail by Lliboutry $(1964-65)$ and Shumskiy (1964). Shumskiy has shown that protocrystallization leads to a pattern with $c$-axes parallel to the interface when the freezing front proceeds from the liquid to the bedrock. For instance, this fabric will develop when a water film flowing over the bedrock is chilled during the night. This situation is likely to occur in the cavities of Glacier de Tsanfleuron, thus explaining the large number of equatorially orientated $c$-axes observed. Furthermore, the same authors have described a random pattern in congelation ice either when the water is flowing or when irregularities in the rock surface act as nuclei for crystallization. Both processes might have been active in the present case, leading to the "mixed" fabric of diagram $\mathrm{Tl}$. In addition, the geometric selectivity which usually appears in the second phase of crystallization has not yet developed here, because the thickness of ice must reach 50-100 times the mean dimensions of the crystals in the initial layer (Shumskiy, 1964).

\section{Deforming ice coatings (Fig. 5, T2)}

The texture is bimodal: the ice crystals are either part of a microcrystalline matrix in which each of them does not exceed $0.5 \mathrm{~mm}^{2}$, or, less of ten, they reach a mean size of $10-40 \mathrm{~mm}^{2}$, which is always larger than those observed in the undeformed ice coatings. Deformation suffered by the latter has therefore strongly altered the ice-crystal shapes and numbers, in a way similar to that described in experimentally deformed ice (Kamb, 1972; Tanaka, 1972; Wilson and Russell-Head, 1982; Duval, unpublished). In these laboratory experiments, the original equidimensional crystals increase in number and decrease in size as stress is applied. Then, as deformation proceeds, the crystal size increases and a new fabric is developed. The small number of large crystals in our sample suggests that recrystallization has only just begun. Indeed, the fabric has not yet been strongly modified: the proportion of equatorially orientated $c$-axes has fallen to $38 \%$, and two groups seem to have appeared in the initially random population, sketching the pattern described below.

\section{Deformed ice coatings incorporated at the sole of the glacier (Fig. 5, T3)}

The trends observed in experimentally deformed ice are confirmed here. The crystals grow in size, becoming similar to those in the glacier ice above, and the crystals' boundaries become more irregular. Now, the fabric has been strongly modified, showing an increased influence of the local glacier-stress conditions. The optic axes are clustered in two groups centred at the theoretical positions of the maxima in pure shear (Fig. 6). In this case, however, deformation is early enough so that the unstable maximum $M_{1}$ is not destroyed.

The links between the different fabrics confirm the mechanism of formation of the basal ice layer suggested above. This mechanism, leading to a rapid disappearance of the fabric of congelation ice, noticeably differs from other mechanisms described in the literature. A "regelation layer" similar to that described from beneath Blue Glacier by Kamb and LaChapelle (1964) has been studied by one of us (Tison, unpublished) in the Swiss Alps. Crystallographic analyses done on this basal ice layer have shown a random pattern which is completely different from that developed in 


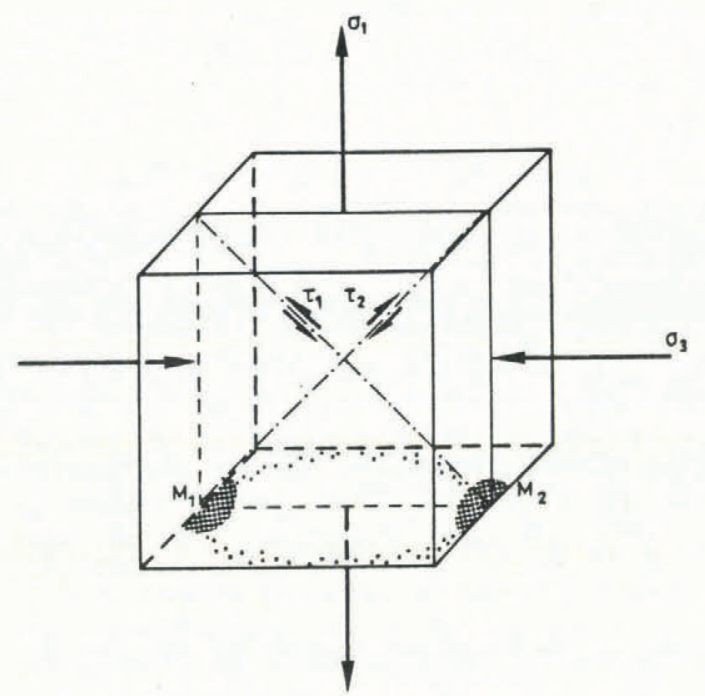

Maxima in pure shear.

Girdle in a general 3-dimensional state of stress

Fig. 6. Theoretical pattern for the optic axes of ice crystals in pure shear and in a general three-dimensional state of stress.

the glacier ice just above and is therefore not affected by the local stress conditions. Moreover, basal ice with a specific petrographic and crystallographic signature has also been observed in other environments (Gow, 1970; Budd, 1972; Anderton, 1974).

\section{CONCLUSION}

Direct observation, and petrographic and crystallographic analyses of the different types of ice sampled at the base of Glacier de Tsanfleuron allow us to suggest the successive stages leading to the formation of an unusual basal ice layer. Major changes in both ice texture and fabric occur during the growth of this basal ice layer. Changes in the form of the subglacial cavities bring the glacier sole into contact with the congelation ice formed on their floors which contain layers of fine debris. This ice is deformed and picked up by the glacier, giving rise to effective stress conditions which erase the initial fabric. Such a basal ice layer may be considered as an effective tool for glacial abrasion since, as indicated by Lemmens and others (1982), it melts down-glacier of the cavities, thus releasing fresh rock particles at the ice-bedrock interface.

The petrographic and crystallographic changes studied here provide confirmation in the field of the deformation mechanisms previously described in laboratory experiments.

\section{REFERENCES}

Anderton, P.W. 1974. Ice fabrics and petrography, Meserve Glacier, Antarctica. Journal of Glaciology, Vol. 13, No. 68 , p. 285-306.

Boulton, G.S. 1970. On the origin and transport of englacial debris in Svalbard glaciers. Journal of Glaciology, Vol. 9, No. 56, p. 213-29.
Budd, W.F. 1972. The development of crystal orientation fabrics in moving ice. Zeitschrift für Gletscherkunde und Glazialgeologie, Bd. 8, Ht. 1-2, p. 65-105.

Duval, P. Unpublished. Fluage et recristallisation des glaces polycristallines. [Thèse de Doctorat d'État, Université Scientifique et Médicale de Grenoble, 1976.]

Gow, A.J. 1970. Deep core studies of the crystal structure and fabrics of Antarctic glacier ice. CRREL Research Report 282.

Hallet, B., and others. 1978. The composition of basal ice from a glacier sliding over limestones, by B. Hallet, R. Lorrain, and R. Souchez. Geological Society of America. Bulletin, Vol. 89 , No. 2, p. 314-20.

Hooke, R. LeB. 1969. Crystal shape in polar glaciers and the philosophy of ice-fabric diagrams. Journal of Glaciology, Vol. 8, No. 53, p. 324-26.

Jouzel, J., and Souchez, R.A. 1982. Melting-refreezing at the glacier sole and the isotopic composition of the ice. Journal of Glaciology, Vol. 28, No. 98, p. 35-42.

Kamb, W.B. 1972. Experimental recrystallization of ice under stress. (In Heard, H.C., and others, eds. Flow and fracture of rocks. Edited by H.C. Heard, I.Y. Borg, N.L. Carter, and C.B. Raleigh. Washington, DC, American Geophysical Union, p. 211-41. (Geophysical Monograph 16.))

Kamb, W.B., and LaChapelle, E. 1964. Direct observation of the mechanism of glacier sliding over bedrock. Journal of Glaciology, Vol. 5, No. 38, p. 159-72.

Langway, C.C., jr. 1958. Ice fabrics and the universal stage. U.S. Snow, Ice and Permafrost Research Establishment. Technical Report 62.

Lemmens, M., and others. 1982. Isotopic composition of ice and subglacially precipitated calcite in an Alpine area, by M. Lemmens, R. Lorrain, and J. Haren. Zeitschrift für Gletscherkunde und Glazialgeologie, Bd. 18, Ht. 2, p. 151-59.

Lliboutry, L. 1964-65. Traité de glaciologie. Tomes 1 et 2. Paris, Masson et Cie.

Maire, R. Unpublished. Recherches géomorphologiques sur les karsts haut-alpins des massifs de Platé, du Haut-Giffre, des Diablerets et de l'Oberland Occidental. [Thèse de Doctorat de 3 e cycle, Université de Nice, 1976.]

Robin, G. de Q. 1976. Is the basal ice of a temperate glacier at the pressure melting point? Journal of Glaciology, Vol. 16, No. 74, p. 183-96.

Shumskiy, P.A. 1964. Principles of structural glaciology, by P.A. Shumskii. New York, Dover Publications.

Souchez, R.A., and De Groote, J.M. 1985. $\delta \mathrm{D}-\delta^{18} \mathrm{O}$ relationships in ice formed by subglacial freezing: paleoclimatic implications. Journal of Glaciology, Vol. 31, No. 109 , p. 229-32.

Souchez, R.A., and Lorrain, R.D. 1978. Origin of the basal ice layer from Alpine glaciers indicated by its chemistry. Journal of Glaciology, Vol. 20, No. 83, p. 319-28.

Tanaka, H. 1972. On preferred orientation of glacier and experimentally deformed ice. Journal of Geological Society of Japan, Vol. 78, No. 12, p. 659-75.

Tison, J.-L. Unpublished. Étude des mécanismes de l'érosion glaciaire latérale par l'analyse chimique et pétrographique des glaces d'un glacier alpin. [Thèse de Doctorat, Université Libre de Bruxelles, 1981.]

Vivian, R. 1975. Les glaciers des Alpes occidentales. Grenoble, Imprimerie Allier.

Weertman, J. 1964. The theory of glacier sliding. Journal of Glaciology, Vol. 5, No. 39, p. 287-303.

Wilson, C.J.L., and Russell-Head, D.S. 1982. Steady-state preferred orientation of ice deformed in plane strain at $-1{ }^{\circ}$ C. Journal of Glaciology, Vol. 28, No. 98, p. 145-60. 